Original Research Paper

\title{
The Development Technique of Side and Budwood Grafting Improving Production of Cocoa in Mamuju Regency West Sulawesi, Indonesia
}

\author{
Ida Suryani \\ Faculty of Agriculture and Technology, Cokroaminoto University, Makassar 90245, Indonesia
}

\author{
Article history \\ Received: $18-10-2020$ \\ Revised: $17-12-2020$ \\ Accepted: 06-02-2021 \\ E-mail: idasuryani8311@gmail.com
}

\begin{abstract}
The one of human effort increasing productivity and high quality of cocoa is rehabilitating plant using plant materials with high production and resistant clones to Cocoa Pod Borer. The common methods using side and budwood grafting technique. The research objectives is to compare two grafting technology for old cocoa plant, community empowerment in developing side grafting of cocoa plants by means improve technical skills and develop of farmers in Mamuju Regency. The research was conducted for two years (2017 and 2018) used locations of farmers cocoa plantation in Papalang District, Mamuju Regency, West Sulawesi, Indonesia. The research was held in the two stages: (1) Consultation and coordination with relevant agencies such as: Plantation Service, Trade Service, Meteorological Agency at Provincial and District levels used interview techniques and secondary data collection (area size, number of cocoa farmers, production and productivity, sale and selling price, climatic and soil condition). This activity gaining support from the local government and other stakeholders related to cocoa development; (2) testing the cocoa vegetative propagation technique by side and budwood grafting at the farmer and seed breeder level. Observations were made on the percentage of successful plant connections, plant growth, number of seeds produced per unit time and business feasibility analysis used the $\mathrm{B} / \mathrm{C}$ ratio. The results were showed that the success rate of the connection achieved was actually higher for side grafting than budwood grafting. The success rates of cocoa clones budwood grafting and side grafting at first month were 83.3 and $90.3 \%$, respectively. Until the fourth month after grafting, the percentage of superior cocoa clones can planted in the plantation still more than $80 \%$. The success rate of cocoa growing in second year (2018) at Papalang District after applied by two technical grafting. There are budwood grafting result only around $88.5 \%$. The side grafting was showed the higher success rate about $94.5 \%$. Finding of research at Mamuju, the attack of Cocoa Pod Borer (CPB) Conopomorpha cramerella Snellen, as the main pest insect of cocoa has potential decreasing plant productivity. As the conclusion of the research: (1) the success rates of superior cocoa clones budwood and side grafting at first month were 83.3 and $90.3 \%$, respectively; (2) in the observation of second year (2018), there are budwood grafting result only around $88.5 \%$. The side grafting was showed the higher success rate about $94.5 \%$; (3) need more effort farmer control $\mathrm{CPB}$ and avoid insect population outbreak very fast in the plantation. This situation will change by transfer of new technology and more support from the Government for increasing cocoa productivity.
\end{abstract}

Keywords: Cocoa, Side Grafting, Budwood Grafting, Cocoa Pod Borer, Productivity 


\section{Introduction}

West Sulawesi Province is one of the cocoa (Theobroma cacao L.) producing areas in Indonesia. It is estimated that $20 \%$ of the national cocoa production comes from the meaning areas. Cocoa has high value commodity in most of the farming community and main source improving family income. Then cocoa is the popular product playing an important role in the economy at Mamuju, West Sulawesi region. Cocoa development in this region on the past was still partial and not implemented intensively. The cocoa production center are located on the island of Sulawesi, with a production of 631.290 tonnes or $67 \%$ of the total national production (DJP, 2013).

In 2009, the Indonesian Government through the Directorate General of Plantation, began developing cocoa to national cocoa center including Mamuju as the producers of cocoa in West Sulawesi. This program is known as the national movement for the improvement of cocoa production and quality (GERNAS). In the similar year, Mamuju district received an allocation for this movement divided into: Rejuvenation of 1.250 hectares, Rehabilitation of 8.000 hectares and Intensification of 5,000 hectares, respectively. Rehabilitation of old cocoa plants by apply side and budwood grafting technique. This is a very strategic activity for Mamuju areas related to cocoa development. This movement can deliver the welfare of cocoa farmers because the movement is carried out professionally and accordance with technical regulations. Although the area and production of Indonesian cocoa have increased rapidly in the last decade, at a rate of $8 \%$ and $5.6 \%$ per year, respectively. The average productivity of Indonesian cocoa has only reached $625 \mathrm{~kg}$ per hectare per year, even though the potential is more than $2.000 \mathrm{~kg}$ per year (DJP, 2013).

The current cocoa production is 435,000 tonnes with production from smallholder plantations around $87 \%$. Effendy et al. (2013b) reported that the highest production, which is $67 \%$ was obtained from cocoa production center in South Sulawesi, Southeast Sulawesi, West Sulawesi and Central Sulawesi.

Indonesian cocoa exports are still mostly produced in semi-finished form and not final processed products. It is different with Singapore and Malaysia which are able to process cocoa beans in the form of using chocolate, while their cocoa planting area is smaller than Indonesia. Therefore, the fact from Singapore and Malaysia will motivate Indonesian cocoa businessmen to increase the number of cocoa processing factories for final production, such as cakes or chocolate candies. The current cocoa production is 435,000 tonnes with production from smallholder plantations around $87 \%$. The highest production about $67 \%$ obtained from the region, while cocoa production is centered in South Sulawesi, Southeast Sulawesi and Central Sulawesi. (Effendy et al., 2013a).
The low production of cocoa is due to the aging of the plants which require rehabilitation efforts. If used old plant without rehabilitation, the cocoa will lead to a process of destruction. This is also influenced by the vegetation in the cocoa plantation area which contributes to the total nitrogen content, especially in horizon a which is still influenced by root residues from trees that grew previously and temporarily decaying (Suryani, 2012). There are a decrease in permiability according to the depth caused by the presence of vegetation and litter on the soil surface and the activity of soil living bodies, especially bacteria that play a role in changing organic matter so that the stability of soil aggregates and pores can be maintained (Suryani, 2014).

The one solution rehabilitation of cocoa old plant through side grafting and budwood grafting. Both of technology is easy to practice, then materials find around cocoa habitat and the price is cheap. According to (Johkan et al., 2009; Sukarmin, 2009; Nan et al., 2009; Suharsi and Puspitasari, 2013) state that successful grafting in cocoa has strong related to photosynthesis ability, age and development stage of plant. Commonly side grafting technique more success than budwood grafting because cambium has many contributed on the cell development in dicotyledoneae group. The presence of defoliation after grafting process as important indicators unsuccessful the treatment. Comparing to side grafting, the another technical is budwood grafting. This working very difficult than other methods applied in dicotyledoneae plant. Sodré and Gomes (2019) state that plant buds as main source of mass plant is limiting number, different quality and very susceptible to environment. These technique need more skills and maintenance in field. In addition, the grafting technology can apply in various forms according to the type of plant, the conditions of the upper and lower stems and the environment in which the propagation technology will be applied. The side grafting technique in cocoa plants is one of the rejuvenation techniques for cocoa plants that are old ( \pm 18 years). This technique used the scion (entris) of superior clone cocoa then attached to the stem of the cocoa plant in order to produce new, more productive plants (Effendy, 2015). This is an innovation in responding to the decline experienced by cocoa plantations, as well as bringing together local knowledge of farmers with knowledge conveyed from outside by the government (Fahmid, 2013; Husnah et al., 2015). Suryani (2012) findings that majority cocoa in Papalang District as old plant in diversity clones. The one cheaper technique and easy applied is side grafting used plant source areas surrounding the plantation. Commonly farmers used side grafting technique as effort increasing their cocoa production.

The research objectives is to compare two grafting technology for old cocoa plant, community empowerment in developing side grafting of cocoa plants by means improve technical skills and develop of farmers in Mamuju Regency. 


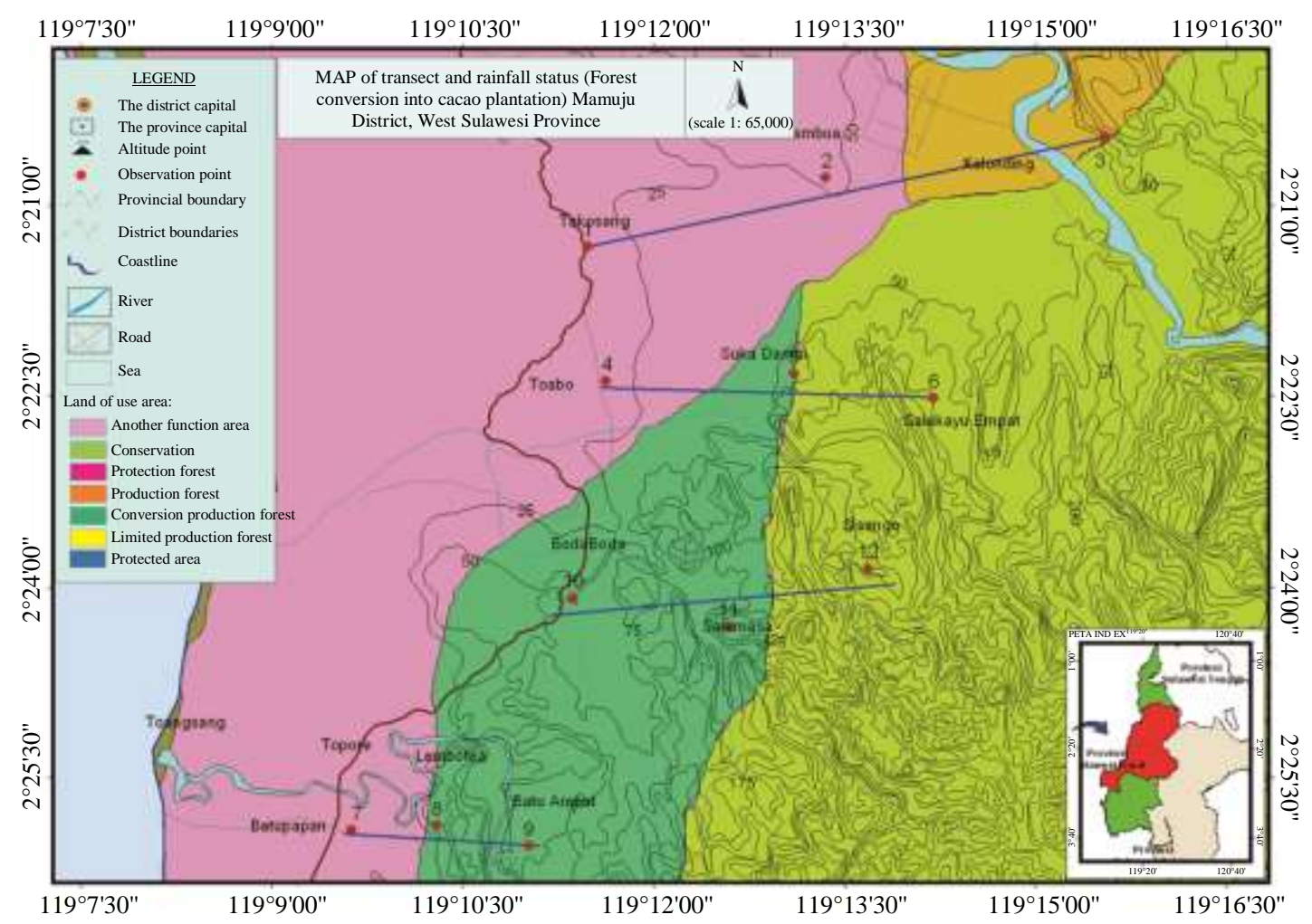

Fig. 1: Cocoa research locations in Mamuju Regency, West Sulawesi, Indonesia

\section{Materials and Methods}

The research of cocoa was conducted in Papalang district, Mamuju Regency, West Sulawesi in 2017 to 2018. Moriarty et al. (2014) reported that commonly farmers in Mamuju derive their income from agriculture and cocoa land for more land use than other crops. Beside cocoa, farmers planting rice in the wet land. Cocoa is the important product from West Sulawesi and the target of export commodities. The cocoa research location was showed in Fig. 1.

The research was carried out in the two stages: (1) Consultation and coordination with relevant agencies such as: Plantation Service, Trade Service, Meteorological Agency at Provincial and District levels used interview techniques and secondary data collection (area size, number of cocoa farmers, production and productivity, sale and selling price, climatic and soil condition). These activities gaining support from the local government and other stakeholders related to cocoa development; (2) testing the cocoa vegetative propagation technique by side and budwood grafting at the farmer and seed breeder level. Observations were made on the percentage of successful plant connections, plant growth, number of seeds produced per unit time and business feasibility analysis used the $\mathrm{B} / \mathrm{C}$ ratio.

\section{Result}

\section{Success Rate Two Grafting Techniques on Cocoa Plants}

Cocoa is the high value commodity in West Sulawesi and increasing the farmers income beside planting a vegetables. The observation about average success rate of budwood and side grafting technique for few superior cocoa clones in Papalang district was presented in Table 1.

Based on Table 1, the highest success rate of budwood grafting on cocoa in the fifth months of observation $(91.2 \%)$. The third and fourth months of observation showed the similar lowest success rates in budwood grafting $(80.1 \%)$. For another technique, the highest side grafting in fourth months of observation resulted $91.3 \%$ not significant to second months of observation $(90.1 \%)$. The lowest result of side grafting in superior cacao clones in second months of observation $(90.1 \%)$.

Papalang District in West Sulawesi as the famous of high quality of Sulawesi cacao. The success rate of cocoa growing was observed in research was showed in Table 2. 
Table 1: The average success rate of budwood and side grafting techniques in superior cocoa clones at Papalang District, Mamuju Regency, West Sulawesi (\%)

\begin{tabular}{lll}
\hline $\begin{array}{l}\text { Months of } \\
\text { observation }\end{array}$ & Success rate in superior cocoa clones (\%) \\
\hline First & Budwood grafting & Side grafting \\
Second & 83.3 & 90.3 \\
Third & 82.4 & 90.1 \\
Fourth & 80.1 & 91.1 \\
Fifth & 80.1 & 90.4 \\
Sixth & 91.2 & 91.3 \\
\hline
\end{tabular}

Table 2: The success rate of cacao growing in the 2017 and 2018 at Papalang District, Mamuju Regency, West Sulawesi, Indonesia

Success rate of cacao growing in farmer plantation (\%)

\begin{tabular}{lll} 
Year & Budwood grafting Side grafting \\
\hline 2017 & 96.4 & 94.5 \\
2018 & 88.5 & 94.5 \\
Total number of trees & 590 & 645 \\
\hline
\end{tabular}

The success rate of cacao growing in farmer plantation used budwood grafting was very high in 2017 $(96.4 \%)$ and decreasing in $2018(88.5 \%)$ with total trees 590. Then, side grafting methods observation in Table 2 was showed, in the 2017 and 2018 has similar resulted $(94.5 \%)$ from 645 cacao trees.

\section{Discussion}

\section{Success Rate of Cocoa Plant Growing used Two Grafting Technology}

The popular methods increasing productivity of cacao used technical effort such as side grafting. In recent years, the another methods such as budwood grafting to be a common methods improving harvest and production of cacao. The results of the observation in Table 1 was showed the implementation on budwood and side grafting at superior cacao clones at Papalang District, Mamuju. Suryani (2012) reported that the commonly superior cacao growth in Papalang District such as: Sulawesi 1 and 2, then supporting of new release cacao clones: ICS 13, ICS 60, RCC 70, ICCRI 03, ICCRI 04, Polman, M01 and Luwu Utara. This superior clones used as substitution majority of old cacao plant in Mamuju.

Based the Table 1, the success rate of the connection achieved was actually higher for side grafting than budwood grafting. The success rates of cocoa clones used budwood grafting in the beginning (about 4th month) in lowest number. After the periods grafting, the percentage of superior cocoa clones can planted in the plantation still more than $80 \%$. This fact showed that farmer has more skill practices side grafting of seedlings than budwood grafting. Technical efficiency such as side grafting methods has a potential increasing cocoa production in different clones. Effendy (2015) finding that cocoa farming application used side grafting technology had a higher level of technical efficiency when compared without grafting technology. Side grafting will survive better and resist to damage than budwood grafting.

The Sulawesi Regional Government has proposed cocoa varieties Sulawesi 1 and Sulawesi 2 become superior seeds in the variety release session. Previously, the regional governments of South Sulawesi, West Sulawesi and Southeast Sulawesi have become the owners of Sulawesi 1 and 2 cocoa varieties. The future plan development of cacao is to build mother gardens in their respective regions. In addition, there are several other superior cocoa clones, namely: ICS 13, ICS 60, RCC 70, ICCRI 03, ICCRI 04, Polman, M01, Luwu Utara which have reported yield success of more than $80 \%$ (Suryani, 2012). The high success rate of side grafting of cocoa because plant stems was easier handling than budwood. Based practices and experience in the cocoa farming, commonly entris used to grafting of cocoa have three buds to avoid unsuccessfull activities. While grafting used only one bud will $100 \%$ failure because no substitute bud for substitute in the same place (Muzari et al., 2012; Zakariyya and Yuliasmara, 2015).

In Mamuju, especially in Kalukku area, which is part of the Samusenga'na cocoa farmer group has 65 hectares with 25 members. They are used cocoa superior clones, namely: S1, S2, ICCIRI, Jumbo and KW 570 which produce 1.5 tonnes per hectare with price USD 5 per $\mathrm{kg}$. Effendy et al. (2013a) state that cocoa from Sulawesi rich by cocoa butter and flavour than another areas. Based the plant genetic of superior cocoa clones, this is the golden opportunity increasing quality of Sulawesi cocoa. Then management of farmer apply Good Agricultural Practices in their cocoa farming will supporting production with high quality.

The rehabilitate of old cocoa plant two methods used budwood grafting and side grafting has purpose increasing productivity of cocoa. Commonly cocoa plant in Papalang District in status lower productivity. This is a reason applied two methods of grafting based future planning of East Sulawesi Government. The observation of farmer cocoa plants growing in second year (2018) in Papalang District, Mamuju Regency after application of two grafting technique was showed in Table 2.

Based on Table 2 was showed the success rate of cocoa growing in second year (2018) at Papalang District after applied by two technical grafting. The cocoa clones commonly used in both technical grafting is Sulawesi 1 and 2. In few years ago, cocoa clones 
Sulawesi 1 and 2 has been recommended as resistant cocoa and high productivity. This is suitable development in dry-land areas with poor of soil mineral. Suryani (2012) reported the another superior cocoa clones complete presence of Sulawesi 1 and 2 is ICS 13, ICS 60, RCC 70, ICCRI 03, ICCRI 04, Polman, M01, Luwu Utara which have reported yield success of more than $80 \%$ of cocoa production in Mamuju.

The findings of research showed the budwood grafting lower than side grafting technology in cocoa plants. The complexity of plant physiology in plant development affecting by stomatal in leaves that responsible in plant life. Brownlee (2001); Bozoglu and Karayel (2006) state that stomatal is the plant organelles that supporting plant life photosynthesis and transpiration. The budwood grafting technique used cocoa buds improving plant production. Unfortunately, the budwood technique resulting lower percentage survival of the cocoa plant. Beside plant genetic condition, the abiotic factor such as: temperature, humidity and $\mathrm{pH}$ of soil affect the survival of plant.

Berry (1974; Bosompem et al., 2011) reported that based the history management of cocoa, side grafting technology commonly used to rehabilitate the old and unproductive of cocoa plants. However, this technique is not used propagation of cocoa seedlings. This technology is carried out by grafting superior cocoa clones (as upper stem) to mature cocoa plant that lower productivity (lower stem). Rahman and Hasan (2008) state that increasing plant productivity need more innovation and apply of more new technology. This situation similar between management plant of staple food and industry.

The research result from (Daouda et al., 2018) was showed the number of leaves was high in top grafting compared to budding or budwood grafting. This is the same trend was observed in the cocoa field. There were no significant differences between both techniques for the grafting success; meanwhile success was $77 \%$ and $68 \%$ for top grafting and budding, respectively. The researcher finding there was better vegetative growth on seedlings grafted using top grafting than budding. Also this technique seems to be the best to graft cocoa in the nursery. Side grafting technology has developed well and some of them has a positive impact on increasing cocoa production. The results showed that after 2 years of cocoa plant, the productivity of them using side grafting reached 2 tonnes per hectare per year. There are harvest only 0.25 tonnes per hectare per year find in old cocoa plant without grafting technology. Budwood grafting technology is the merging of two individual clones of different cocoa plants into one unit and growing into a new plant. This technology used cocoa seedlings as lower stem then connected to the scion from the superior cocoa plants which become the upper stems. In general, cocoa seeds that become lower stem are ready in treatment at the age of 2.5 to 3 months. Effendy (2015) reported that the basic principle of the budwood grafting technique is the fusion of the cambium was formed between the scion and lower stem. Cambium in plant playing an important role in the process of healing injury on plant stems.

\section{Effort Increasing Farmers Knowledge and Skill}

The knowledge and experience of farmers in implementing technology in cocoa plantation is quite adequate. However, the attack and injury of Cocoa Pod Borer (CPB) Conopomorpha cramerella Snellen, as the main pest insect of cocoa has potential decreasing plant productivity. This is very difficult condition for farmers to control because insect population outbreak very fast in the plantation. Day (1989; Rosmana et al., 2010) reported that larvae of CPB feeding resulting in pods ripen prematurely caused small beans. The are often stuck together in a mass of dried mucilage. They are separating faster by invasion the adult of CPB. The commonly technique farmers used control the CPB is cultural practices such as: sanitation, frequent and complete harvesting.

This situation need to be changed with the transfer of new technology and more support from the Government for increasing cocoa productivity. Klerkx and Leeuwis (2008; Oreszczyn et al., 2010) state that demand and supply in the agricultural product need more attention to apply new technology to reduce farmers welfare management presence of CPB in cocoa plantation. Teh et al. (2006; McMahon et al., 2009) reported that majority cocoa tree in West Sulawesi (region Mamasa and Mamuju) as the old tree (more than 10 years) and very susceptible to CPB. Also, the old tree caused decline in cocoa production. They has negatively impacted household income, then majority of cocoa smallholders earn income from other sources such as rice farming. Many cocoa smallholders do not understand the reasons for their decline in yield and would benefit from understanding the impacts of aging trees and pests. Effendy et al. (2013b) reported, to anticipate problem of cocoa declines, farmers in Sigi Regency Indonesia has adoption new technology of side-grafting in increasing cocoa production. Side grafting technology increasing plant growth related to the mass production of cocoa.

Increasing knowledge and skills of farmers through innovation technology plant productivity programmed. The activities in training and extension using the field school method. Through the field school, communication between farmers and other stakeholders will be established to solve various cocoa problems. The improvement of these strategic factors requires policy and funding support, especially for fixing or revitalizing extension institutions and programs. One of the work programs that is very urgent to be addressed is the integrated and comprehensive as Cocoa Pod 
Borer pest control program. Tovey (2008) suggested that priority of the urgent program will help increasing plant productivity especially in case the old cacao plant at Mamuju Regency.

Institution as a main source of new technology, playing a role increasing cocoa productivity. The institutions, stake holder and farmer groups join and dealing increasing cocoa productivity by adoption of new technology. The farmer group functions as a learning forum for cocoa farmers such as discussion and conducting policy advocacy for cocoa farmers. In general, the formation of farmer groups in Mamuju was initiated by farmers. However, in the current condition, the majority of registered farmer groups are no longer functioning. There are few farmer groups formed only to get financial assistance from the government. Then institution formed is an agricultural cooperative which functions as a forum to support cocoa farming activities in Mamuju. For its development, cooperatives need to be managed professionally to improve farmers welfare. Bruckmeier and Tovey (2008); Fahmid (2013) suggested that priority between application of technical and social innovation started to a serious conlicting paradigms and sustained challenge in the farmers and government. The similar research from (Lamine, 2005; Geels and Schot, 2007; Tovey, 2008; Silva et al., 2011) finding that the innovation with collective and creative learning methods will be able to generate new skills, new products and practices, as well as new attitudes and values. This recommendation for increasing capacity knowledge and skill of farmers in Mamuju Regency, West Sulawesi.

\section{Conclusion}

The conclusion of research is:

1) The success rates of superior cocoa clones bud wood and side grafting at first month were 83.3 and $90.3 \%$, respectively

2) The observation of second year (2018), there are bud wood grafting result only around $88.5 \%$. The side grafting was showed the higher success rate about $94.5 \%$

3) Need more effort farmer control CPB and avoid insect population outbreak very fast in the plantation. This situation will change by transfer of new technology and more support from the Government for increasing cocoa productivity

\section{Acknowledgement}

This study as my private research at Papalang District, Mamuju West Sulawesi. I would like to say thank you very much to $\mathrm{H}$. Ilyas (owner of cocoa plantation), Roni Ritonga, ST (assistant research in field), Dr. Ismaya Parawansa, SP., M.Si and Nur Fitriani, $\mathrm{SE}$ (collected and tabulation of data research).

\section{Ethics}

This article is original and contains unpublished material. The corresponding author confirms that all of the other authors have read and approved the manuscript and no ethical issues involved

\section{References}

Berry, S. S. (1974). The concept of innovation and the history of cocoa farming in western Nigeria. Journal of African History, 83-95. https://www.jstor.org/stable/180371

Bosompem, M., Kwarteng, J. A., \& Ntifo-Siaw, E. (2011). Perceived impact of cocoa innovations on the livelihoods of cocoa farmers in Ghana: the sustainable livelihood framework (Sl) approach. Journal of Sustainable Development in Africa, 13(4), 285-299. http://www.jsd-

africa.com/Jsda/Vol13No4_Summer2011_B/PDF/Perc eived $\% 20$ Impact $\% 20$ of $\% 20$ Cocoa $\% 20$ Innovations $\% 2$ 0of\%20the\%20Livelihoods1.pdf

Bozoglu, H., and Karayel, R. (2006). Investigation of stomata densities in pea (Pisum sativum L.) lines/cultivar. Online Journal of Biological Sciences, $6(2)$

56-61. https://pdfs.semanticscholar.org/17d9/972b0707b6456 1183876b5d28cee30a2bda0.pdf

Brownlee, C. (2001). The long and short of stomatal density signal. Trend in Plant Sci., 6: 441-442. https://www.sciencedirect.com/science/article/abs/pii/S 1360138501020957

Bruckmeier, K., \& Tovey, H. (2008). Knowledge in sustainable rural development: from forms of knowledge to knowledge processes. Sociologia ruralis, 48(3), 313-329.

Daouda, K. K., Jane, K., Lucien, D., Jean-Luc, K., Kouadio, B., \& Christophe, K. E. (2018). Comparison of grafting techniques and their effects on some growth parameters of ten elite cocoa clones (Theobroma cacao L.). African Journal of Agricultural Research, 13(41), 2249-2255.

Day, R. K. (1989). Effect of cocoa pod borer, Conopomorpha cramerella, on cocoa yield and quality in Sabah, Malaysia. Crop Protection, 8(5), 332-339. https://www.sciencedirect.com/science/article/abs/pii/0 261219489900525

DJP. (2013). Production and productivity of cocoa based on province in Indonesia.

Effendy. (2015). Application of Side-Grafting Technology to Increase Cocoa Productivity: Case Study in Sigi Regency Indonesia. Journal of Applied $\quad$ Science, 15: 715-718. https://scialert.net/abstract/?doi=jas.2015.715.718 
Effendy, H. N., Setiawan, B., \& Muhaimin, A. W. (2013a). Characteristics of farmers and technical efficiency in cocoa farming at Sigi Regency-Indonesia with approach stochastic frontier production function. $\mathrm{J}$ of Econ and Sust Develop, 4(14), 154-160. https://www.iiste.org/Journals/index.php/JEDS/article/ view/7833

Effendy, H. N., Setiawan, B., \& Muhaimin, A. W. (2013b). Effect characteristics of farmers on the level of technology adoption side-grafting in cocoa farming at Sigi Regency-Indonesia. J. Agric. Sci., 5: 72-77. http://www.ccsenet.org/journal/index.php/jas/article/vi ew/29702

Fahmid, I. M. (2013). Social innovation among ethnics in cocoa farming at Sulawesi, Indonesia. Journal of Biology, 3(11).

Geels, F. W., \& Schot, J. (2007). Typology of sociotechnical transition pathways. Research policy, 36(3), 399-417. https://www.sciencedirect.com/science/article/abs/pi i/S0048733307000248

Husnah, N., Ali, M. S. S., Salman, D., Hijjang, P., Djufry, F., \& Amrawaty, A. A. (2015). Merging indigenous and modern knowledge in agricultural development. International Journal of Agriculture System, 2(2), 141-151.

Johkan, M., Mitukuri, K., Yamasaki, S., Mori, G., \& Oda, M. (2009). Causes of defoliation and low survival rate of grafted sweet pepper plants. Scientia Horticulturae, 119(2), 103-107. https://www.sciencedirect.com/science/article/abs/pi i/S030442380800280X

Klerkx, L., \& Leeuwis, C. (2008). Matching demand and supply in the agricultural knowledge infrastructure: Experiences with innovation intermediaries. Food policy, 33(3), 260-276. https://www.sciencedirect.com/science/article/abs/pi i/S0306919207000553

Lamine, C. (2005). Settling shared uncertainties: local partnerships between producers and consumers. Sociologia ruralis, 45(4), 324-345.

McMahon, P., Iswanto, A., Susilo, A. W., Sulistyowati, E., Wahab, A., Imron, M., ... \& Keane, P. (2009). On-farm selection for quality and resistance to pest/diseases of cocoa in Sulawesi:(i) performance of selections against cocoa pod borer, Conopomorpha cramerella. International Journal of Pest Management, 55(4), 325-337. https://www.tandfonline.com/doi/abs/10.1080/0967 0870902923438

Moriarty, K., Elchinger, M., Hill, G., Katz, J., \& Barnett, J. (2014). Cacao intensification in Sulawesi: a green prosperity model project (No. NREL/TP-540062434). National Renewable Energy Lab.(NREL), Golden, $\quad \mathrm{CO}$ (United States). https://www.osti.gov/biblio/1156964
Muzari, W., Gatsi, W., \& Muvhunzi, S. (2012). The impacts of technology adoption on smallholder agricultural productivity in sub-Saharan Africa: A review. Journal of Sustainable Development, 5(8), 69. https://pdfs.semanticscholar.org/2b9b/4f7bd514ae8a28 a1108f43892950da4b592b.pdf

Nan, Z., Mei-ling, W., Hong-tao, W., \& Xi-zhen, A. (2009). Effects of grafting on photosynthesis of sweet pepper seedlings under low temperature and weak light intensity. Yingyong Shengtai Xuebao, 20(3).

Oreszczyn, S., Lane, A., \& Carr, S. (2010). The role of networks of practice and webs of influencers on farmers' engagement with and learning about agricultural innovations. Journal of Rural Studies, 26(4), 404-417. https://www.sciencedirect.com/science/article/abs/pi i/S0743016710000227

Rahman, S., \& Hasan, M. K. (2008). Impact of environmental production conditions on productivity and efficiency: A case study of wheat farmers in Bangladesh. Journal of Environmental Management, $88(4)$, 1495-1504 https://www.sciencedirect.com/science/article/pii/S0 301479707002861

Rosmana, A., Shepard, M., Hebbar, P., Mustari, A., Cocoa Research Group \& Cocoa Research Group. (2013). Control of cocoa pod borer and Phytophthora pod rot using degradable plastic pod sleeves and a nematode, Steinernema carpocapsae. https:/explore.openaire.eu/search/publication?articl eId=od-2356::4736791d006bfb3df3db4879a090c7fd

Silva, T. E., Cidade, L. C., Alvim, F. C., Cascardo, J. C., \& Costa, M. G. (2009). Studies on genetic transformation of Theobroma cacao L.: evaluation of different polyamines and antibiotics on somatic embryogenesis and the efficiency of uidA gene transfer by Agrobacterium tumefaciens. Plant Cell, Tissue and Organ Culture (PCTOC), 99(3), 287-298. https://link.springer.com/article/10.1007/s11240009-9603-1

Sodré, G. A., \& Gomes, A. R. S. (2019). Cocoa propagation, technologies for production of seedlings. Revista Brasileira de Fruticultura, 41(2). https://www.scielo.br/scielo.php?pid=S010029452019000201003\&script=sci_arttext

Suharsi, T. K., \& Sari, A. D. P. (2013). Pertumbuhan mata tunas jeruk keprok (Citrus nobilis) hasil okulasi pada berbagai media tanam dan umur batang bawah rough lemon (C. jambhiri). Jurnal Ilmu Pertanian Indonesia, 18(2), 97-101. https://jurnal.ipb.ac.id/index.php/JIPI/article/view 18380

Sukarmin, I. F. E. 2009. Teknik perbanyakan F1 mangga dengan menggunakan batang bawah dewasa melalui sambung pucuk. Bul Tekn Pertani, 14(2), 58-61. 
Suryani, I. (2012). The vegetation on the total nitrogen content of the various soil depth in the area of cocoa in Papalang, Mamuju District. Jurnal Agrisistem, 9(1): $\quad 49-54 . \quad$ http://ejournal.polbangtangowa.ac.id/index.php/J-Agr/article/view/31

Suryani, I., (2014). Permeability various soil depth in forest land area conversion. Jurnal Agrisistem, 10(1): 92-98. http://ejournal.polbangtangowa.ac.id/index.php/J-Agr/article/view/28

Teh, C. L., Pang, J. T. Y., \& Ho, C. T. (2006). Variation of the response of clonal cocoa to attack by cocoa pod borer Conopomorpha cramerella (Lepidoptera: Gracillariidae) in Sabah. Crop Protection, 25(7), 712-717.

https://www.sciencedirect.com/science/article/abs/pi i/S0261219405002644
Tovey, H. (2008). Introduction: rural sustainable development in the knowledge society era. Sociologia Ruralis, 48(3), 185-199.

Zakariyya, F., \& Yuliasmara, F. (2015). Top grafting performance of some cocoa (Theobroma cacao L.) clones as affected by scion budwood number. Pelita Perkebunan (a Coffee and Cocoa Research Journal), 31(3), 163-174. https://www.ccrjournal.com/index.php/ccrj/article/vi ew/198 